\title{
PHILOSOPHICAL TERMS AND CONCEPTS AN THEIR FUNCTIONAL UNIQUENESS THROUGH THE PRISM OF LEXICAL ANALYSIS OF THE RENAISSANCE
}

\author{
Denis Bakhtiyorovich Sadullaev \\ English Chair, Bukhara State Medical Institute, Uzbekistan
}

\section{ABSTRACT}

This article claims to identify the fundamental functions of philosophical terms and concepts in the text, their historical formation and evolution through the prism of world, and in particular, English philosophical literature of the Renaissance, as well as establishing and defining the characteristic features of the functioning of philosophical concepts and terms based on lexical materials of world literature.

KEYWORDS: - Philosophical terminology, lexical units, concept, term, terminological system, philosophical vocabulary, Renaissance, differentiation, presupposition, lexical-semantic variant (LSV).

\section{INTRODUCTION}

Philosophical terms and their functional peculiarity have always been a specific aspect of lexicalsemantic field of English philosophical literature beginning fro the Renaissance epoch and further. In order to determine the basic tendencies that characterize the main composition of the philosophical vocabulary aimed at a specific topic in many aspects, it becomes necessary to trace the transformations that are determined by the time factor. New layers of vocabulary, both borrowed from Latin through the mediation of the French language, and previously used only in everydaycolloquial style, are included in the written-literary language, through and with the help of which new concepts are expressed, a new interpretation of the semantics of lexical units, in the light of the affirmed materialistic system of F. Bacon, "the true ancestor of all experimental science."

The enrichment of the language of the era with borrowed lexical units was due to powerful shifts in the entire social and political life of England in the 16th-17th centuries. A large number of authors, speaking in various genres, each in their own way tried to explain the humana studia of the era (poetry, prose, songs, verse dialogues, different types of drama, political and scientific treatises, sermons, pamphlets, travel descriptions, historical chronicles ). A similar linguistic situation, when Latin dominated in such areas as science, political life, education, upbringing and religion, influenced the lexical composition and the totality of syntactic methods of organizing linguistic material of a philosophical nature in various spheres and genres. 
CURRENT RESEARCH JOURNAL OF PHILOLOGICAL SCIENCES 2(11):

22-28, November 2021

DOI: https://doi.org/10.37547/philological-crjps-02-11-07

ISSN 2767-3758

(C)2021 Master Journals

Crossref doi

\section{Methods}

The use of philosophical vocabulary in the overwhelming majority of genres is one of the characteristic features of the literature of the era. At the same time, the acquisition by lexical units of new meanings, shades characteristic of the expression of philosophical thought, testifies to the fact that there is a process of gradual professional differentiation of the language of philosophy in connection with the specialization of knowledge, its formalization into a separate science (anticipation "anticipation", concurrence "coincidence", gradation "gradation", etc.): "anticipation is when we prevent those wordes that another would saie" (T. Wilson. Rtet.100); "so shall my anticipation prevent your discovery" (Shaks. Haml. 11.2.304).

Unambiguous lexical units differ in insignificant frequency, however they have a high degree of semantic autonomy, independent of context (modesty "modesty", presupposition "presupposition", ratiocination "reasoning"), "..is according to the light and pre $\urcorner$ supposition of that which is delivered "-" ... is in accordance with the clarity and presupposition of what is being said "(F.Bacon. Adv.L. 11.126); "withot any discourse of reason, or ratiocination" - "... without any discourse in reasons or reasoning" (Holland Plutarch, Mog. 1344); "..be pastime passing excellent, if it be ... with modesty" - "... be great entertainment if it is connected ... with modesty" (Shaks.lnd.1.66); "The that which maiden modestie doth warrant, bet all my sins look meray" - "that female modesty ... justifies ... all my pains look insignificant ..." (Ado.IV. 181).

There is: 1) a significant increase in the nest of word combinations from 2 to 32 lexical units while maintaining the main word as the nucleus of the combination and 2) an increase in the number of LSV. These two conditions indicate a noticeable development of the semantic structure of words of a philosophical nature. The complication of the semantic structure of the analyzed words confirms the idea of their complete assimilation in the semantic sense. All interacting meanings of words play the role of clarifying, concretizing components of the primary borrowed meaning.

By its origin, the philosophical vocabulary is divided into:

1) words arising from the native native vocabulary and

2) words borrowed from other languages.

Some features of the introduction of new borrowed units into everyday life are noted: a) author's interpretations in dictionaries, where by their very nature simplicity and clarity of presentation are inherent; b) periphrases - usually by descriptive translation or through the use of synonyms, for example: ratiocination is, that cometh of logic of any Commodity, or to echeve any discomodity, levity, lightnesse, inconstancie; - "an attempt to reasonably substantiate means to proceed from the logic of any convenience or ... to achieve any inconvenience, frivolity, superficial thinking, inconstancy."

In a significant number of cases, the author introduces a word without interpretation, counting on the linguistic erudition of the reader, while the context helps to determine the meaning of the lexical unit being introduced: In the mysteries of the Christes person, there is no transition of the deitie into the humanite or humanite into the deitie - "In the mysteries of the person of Christ, there is no transition of deity into human form or vice versa" (Gard. Explication of transub-stantiaton, 123).

It is necessary to distinguish between words that relate to philosophical vocabulary and express important, fundamental concepts of a given sphere (fact "fact", agent "agent", coherence "consistency", modesty "modesty", levity "gullibility"), from words 
CURRENT RESEARCH JOURNAL OF PHILOLOGICAL SCIENCES 2(11):

22-28, November 2021

DOI: https://doi.org/10.37547/philological-crjps-02-11-07

ISSN 2767-3758

(C)2021 Master Journals

sones

81 Google

Accepted25 ${ }^{\text {th }}$ November, 2021 \& Published $30^{\text {th }}$ November, 2021

that are philosophical terms in the analyzed period: ratiocination "reasoning", gradation "gradation", medium "medium", ubiquity "omnipresence", reflex "reflection", materiality "materiality", prescupposition "assumption").

The manner of presentation in the first person was typical in the analyzed era (letters, sermons, pamphlets, poetry), which is confirmed by the predominance of personal active forms of the verb, which have a semantic shade of assessment, the author's "I", as well as a personalized form of presentation (psalm, poetry, treatise), reflected in the selection of vocabulary, especially with the verbs of physical action and with the verbs "evaluation, judgment, intention". These lexical units belong not only to scientific philosophical literature, but are also widely used in works of a very different genre: poetry, drama, treatises, sermons, correspondence, polemical articles, which allows us to conclude that during the period under study in In general, philosophical vocabulary has not yet been strictly limited within the framework of the terminology system, i.e. was not a "pure" affiliation of philosophy, but manifested itself as a common vocabulary for expressing the philosophical thought of authors whose works are characterized by different genre orientations. This confirms the general historical tendency - the fact of the encyclopedic education of the representatives of the Renaissance and, accordingly, the various fields of application of their abilities.

Lexical units of a philosophical nature in the XVIXVII centuries. used in various genres. This especially applies to words from the field of ethics (modesty, levity, constancy, coherence), expressing the moral and ethical qualities of a person and to words with broad semantics (fact, gradation). The attraction of these groups is due to the fact that they are characterized by abstraction, are used mainly in the style of written speech (F. Bacon, C. Marlo,
Shakespeare, T. Grafton, J. Milton, Stow, G. Fletcher, Cox).

A number of words from the very beginning belong to the philosophical scientific terminology: reflex, ratiocination, anticipation, pressupposition). The scope of their distribution is very narrow - they are present in works of a philosophical nature (treatises, essays): "... great progress ever be made in science by means of anticipations" - "... progress in science is always achieved with the help of anticipation ( foresight) "(NO262); "by means of anticipation, that is to say, of the reasoning which is now in use" - "with the help of anticipation, that is, reasoning ..." (N.0.262); "presuppositions must seak assistance from similitudes and comparisons" "assumptions should be based on similarities and comparisons" (F. Bacon. De Augm.V. 532).

In the analyzed texts, as the study has shown, usually microfield units are first attached to the term, i.e. a set of special lexical units combined with a given word within the terminological system, and later - words of the general literary language. For example, the compatibility of the lexical unit of ratiocination in the first 100 years on English soil: process of-; discourse of-; to evidence-, to evince-; reason or-. 15 words - innovations of the Latin character are conjugated with words with similar (but not the same semantics): anticipation, coherence, correlation, elucidation, education, gradation, identity, levity, modesty, materiallity, penalty, ratiocination, reflex, transition. These words, as we believe, being an integral part of the commonly used vocabulary (178 words in total), play the role of an intermediary in replenishing the reserves of a layer of philosophical vocabulary.

A certain number of conjugating words that arose within the same (XVI) century stand out: hardheartedness "hardness (thoughts)", falsity "fallibility", deceitfulness "deceit"; perspicuity 
CURRENT RESEARCH JOURNAL OF PHILOLOGICAL SCIENCES 2(11):

22-28, November 2021

DOI: https://doi.org/10.37547/philological-crjps-02-11-07

ISSN 2767-3758

(C2021 Master Journals

Crossref do

gil Google

Accepted $25^{\text {th }}$ November, 2021 \& Published $30^{\text {th }}$ November, 2021

"clarity (of presentation)"; inclination "inclination"; reflection "reflection"; the vulgar "commoner"; forecast "foresight"; epitome "total". Observed in the English language of an older period and in the Middle Ages, the polysemantic semantics of these conjugating words, expressing a particular concept, in the 16th century gives way to a clearer and more unambiguous expression of the concept.

\section{Conclusion}

The results of comparing the semantic structure of the studied units in the analyzed period and in modern English (based on the nouns of the literarybook style) confirm the working hypothesis about the comparative simplicity of the structure of the semantic structure of words of an abstractphilosophical nature.

English abstract philosophical vocabulary acts as a multidimensional system, characterized by the presence of numerous transitional cases, thus reflecting the complexity of relationships and interconnections of its constituent units.

Philosophical vocabulary is also subject to processes that are characteristic of all Latin borrowings of the 16th century.

Thus, philosophical vocabulary appears before us as a single, integral system, subordinate to certain objective laws of history and thinking, reflecting the really existing dialectical relationship and further development of the most important philosophical concepts, worldview of representatives of the late Renaissance. It is indicative that in the foreground is that part of the vocabulary that is directly related to the central concepts of the philosophy of humanism (reflex, modesty, levity, identity, coherence, antitipation, education, correlation).

The Renaissance epoch most decisively influenced not only the content, but also the composition of the philosophical vocabulary, as evidenced by the appearance in the studied era (XV-XVII centuries) of a large number of words to explain the new worldview and worldview in the light of the revolutionary scientific discoveries of the era.

The presence of philosophically "targeted" words among playwrights, poets, theologians suggests that their authors mastered a new worldview, and were also well acquainted with the main works of a philosophical nature of the old and new times, with the vocabulary used in such works.

\section{REFERENCES}

1. Budagov R.A. What is language development and improvement? - M .: Nauka, 1977- P.76.

2. 2.Yartseva V.N. Development of the national literary English language. M., 1964.- S. 122.

3. Ufimtseva A.A. Word in the lexico-semantic system of the language. -M. Science, 1974 - P. 13.

4. Shadmanov K. Features of English philosophical thought and vocabulary of the XIV-XVII centuries. T .: TFI, 2003.- P. 66.

5. Donskoy V.F. Verbal phraseological units denoting the beginning and end of a person's life in the language of the New England period: Abstract of the thesis ... Candidate of Philological Sciences. -M., 1977. -S. 23.

6. Krasilnikova M.S. Origin, semantic structure and some syntagmatic connections of English nouns of a literary and book nature: Abstract of the thesis ... candidate of philological sciences. - M., 1978 .-- P. 16.

7. Vinogradov V.V. Lexicology and Lexicography. Selected work. - M .: Nauka, 1977 - S. 312.

8. Ufimtseva A.A. Word in the lexico-semantic system of the language. - M. Nauka, 1968 .-1980 - S. 580.

9. Ufimtseva A.A. Word in the lexico-semantic 
CURRENT RESEARCH JOURNAL OF PHILOLOGICAL SCIENCES 2(11):

22-28, November 2021

DOI: https://doi.org/10.37547/philological-crjps-02-11-07

ISSN 2767-3758

(C)2021 Master Journals

Crossref do

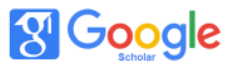

Accepted25 $5^{\text {th }}$ November, 2021 \& Published 30th November, 2021

system of the language. -M. Science, 1968 -- P. 251.

10. Yartseva V.N. Development of the national literary English language. -M .: Science. 1969 p. 95.

11. Sadullaev D. B. Philosophical understanding of terms and concepts by an author as an object of linguistic investigations //Молодой ученый. - 2020. - №. 22. - С. 627-631.

12. Sadullaev D. B. (2020). Historical reality concepts. ISJ Theoretical \& Applied Science, 04 (84), pp. 414- 419

13. Sadullaev Denis Bakhtiyorovich 2020. Concerning the history, formulation and interpretation of the conversion's issue in english language. International Journal on Integrated Education. 3, 3 (Mar. 2020), 95-97. D0I:https://doi.org/10.31149/ijie.v3i3.96.

14. Sadullaev D. B., Ostonova S. N., Shodiev S. S. Interpretation of philosophical terms and concepts as an essential subject for linguistic researches of xix-xx centuries, held in Russia and Europe // ACADEMICIA: An International Multidisciplinary Research Journal. Year : 2020, Volume : 10, Issue : 10, First page : ( 590) Last page : ( 598), Online ISSN : 22497137. Article DOI : 10.5958/22497137.2020.01171.4

15. Sadullaev, Denis Bakhtiyorovich Terminology as a separate scientific field and its actual position in modern linguistics // ACADEMICIA: An International Multidisciplinary Research Journal. Year : 2020, Volume : 10, Issue : 11, First page : ( 1964) Last page : (1973), Print ISSN : 0000-0000. Online ISSN : 2249-7137. Article DOI : $\quad 10.5958 / 2249-$ 7137.2020.01486.X

16. Sadullaev, Denis B. "Problems of Understanding Philosophical Text as a Linguistic Phenomenon." JournalNX, vol. 6, no. 06, 2020, pp. 128-136.

17. Шадманов Курбан Бадриддинович, \&
Садуллаев Денис Бахтиерович (2019). Из истории становления системы основных понятий английской философии. Наука и образование сегодня, (10 (45)), 40-43.

18. Садуллаев Д. Б. Форма существования языка //81.2 г (5У) Ш 16. - 2019. - С. 201.

19. Sadullaev Denis Bakhtiyorovich Linguistic combinatory processes "assimilation" and "borrowing" as a basis for the development of modern english terminology // Asian Journal of Multidimensional Research (AJMR). Year : 2020, Volume : 9, Issue : 11, First page : (33) Last page : ( 38), Online ISSN : 2278-4853. Article DOI : $10.5958 / 2278-$ 4853.2020.00297.9

20. Shadmanov Kurban Badriddinovich, Sadullaev Denis Bakhtierovich From the history of the formation of the system of basic concepts of English philosophy // Science and education today. 2019. No. 10 (45). URL: https://cyberleninka.ru/article/n/iz-istoriistanovleniya-sistemy-osnovnyh-ponyatiyangliyskoy-filosofii

21. Obidovna, D. Z., \& Sadullaev Denis. (2021). Formulas of speech etiquette in a genderengineered communication strategy. Central asian journal of theoretical \& applied sciences, 2(6), 5-11. Retrieved from http://cajotas.centralasianstudies.org/index.p hp/CAJOTAS/article/view/180

22. Bakhtiyorovich, S. D. (2021). Term: definition of the concept and its essential features. Central asian journal of theoretical \& applied sciences, 2(6), 12-18. Retrieved from http://cajotas.centralasianstudies.org/index.p $\mathrm{hp} / \mathrm{CAJOTAS} /$ article/view/181

23. Бахтиерович, С. Д. (2021). Терминологические единицы сквозь призму комбинаторно-компонентного и функионально-синтаксического анализа. Central asian journal of theoretical \& applied sciences, 2(6), 23-29. Retrieved from 
CURRENT RESEARCH JOURNAL OF PHILOLOGICAL SCIENCES 2(11):

22-28, November 2021

DOI: https://doi.org/10.37547/philological-crjps-02-11-07

ISSN 2767-3758

(C)2021 Master Journals

Crossref do

81 Google

Accepted $25^{\text {th }}$ November, 2021 \& Published $30^{\text {th }}$ November, 2021

http://cajotas.centralasianstudies.org/index.p $\mathrm{hp} /$ CAJOTAS/article/view/183

24. Sadullaev, D. B. (2021). Renaissance And Renaissance Philosophical Texts Through The Prism Of Historical Approach. The American Journal of Social Science and Education Innovations, 365), 364-371. https://doi.org/10.37547/tajssei/Volume03Is sue05-67

25. Садуллаев Д. Б. Philosophical understanding of terms and concepts by an author as an object of linguistic investigations //Молодой ученый. - 2020. - №. 22. - С. 312.

26. Sadullaev D. B. (2020). Concerning the history, formulation and interpretation of the conversion's issue in english language. International Journal on Integrated Education, 3, 3 (Mar. -2020

27. Бахтин M. M. Проблемы поэтики Достоевского. М.: Советский писатель, 2013. $364 \mathrm{c}$.

28. Лансон Г. Метод в истории литературы / Пер. и послесл. М. Гершензона. М.: Товарищество Мир, 1911. 428 с.

29. Лихачев Д. С. Древнеславянские литературы как система // VI Международный съезд славистов. Прага, 2015. C. 3-10

30. Shahobiddin Sharofiddinivich Shodiev Islam in the evolution of social and political views of the Uzbek Jadids, their role in the formation of the idea of National Independence // CENTRAL ASIAN JOURNAL OF SOCIAL SCIENCES AND HISTORY. - Feb. 2021. №VOLUME: 02 ISSUE: 02. - C. 45-50.

31.31. Shahob Sharofitdinovich Shodiev. Academicia An International Multidisciplinary Research Journal "Interpretation of philosophical terms and concepts as an essential subject for linguistic researches of xix-xx centuries,held in russia and Europe" 590-98 10.5958/2249-7137.2020.01171.4
32. 32. Shahobiddin Sharofiddinovich Shodiev. Bakaev Najmiddin Bakaevich. expressions.. (2020). The role of the Latin language in the history of world statehood. ISJ Theoretical \& Applied Science, 05 (85), 367-372. Soi: http://s-o-i.org/1.1/TAS-05-85-71 Doi: https://dx.doi.org/10.15863/TAS Scopus ASCC: 1203 . The role of the latin language in the history of world statehood

33. Sh.Sh.Shodiyev. N.B.Bakayev. M.N.Khafizova, S.N.Ostonova " shakespears lexicon: reason word as a design of the concept of the ability of the human mind to abstraction, conclusion " Theoretical and Applied Science, 162-166, 2020

34. Ш.Ш. Шодиев, Д.Я.Шигабутдинова. «Шекспировский лексикон: слово reason как обозначание понятия способности человеческого ума к абстракции умозаключению» Инновационный потенциал развития науки в современном мире, 189-197, 2020

35. 35 . General cultural and educational values of ancient-classic latin language $\mathrm{TN}$ Zayniddinovn, SS Sharofiddinovich central asian journal of theoretical \& applied sciences 2 (5), 77-80 2021

36. 36. Islam in the evolution of social and political views of the Uzbek Jadids, their role in the formation of the idea of National IndependenceKB Shadmanov, SS Shodiev, TN Zayniddinovna Central asian journal of social sciences and history 2 (2), 44-50 2021

37. Sadullaev, D. B. (2021). Reduction Of A Term In A Scientific Theory. The American Journal of Applied Sciences, 3(05), 123-131. https://doi.org/10.37547/tajas/Volume03Iss ue $05-19$

38. Shodiyev Shaxobiddin Sharofiddinovich, \& Tasheva Nafisa Zayniddinovna. (2021). The role of the way of the great steppe in the continuity and relationship of the philosophy 
CURRENT RESEARCH JOURNAL OF PHILOLOGICAL SCIENCES 2(11):

22-28, November 2021

DOI: https://doi.org/10.37547/philological-crjps-02-11-07

ISSN 2767-3758

(C)2021 Master Journals

crossref do) 801 Google

Accepted25 $5^{\text {th }}$ November, 2021 \& Published 30th November, 2021

and culture of the muslim east and the renaissance west. Innovative academy research support center, 1(3), 9-13. Http://doi.org/10.5281/zenodo.4925956

39. Shodiev Shahobiddin Sharofiddinovich, \& Majitova Nafisa Zokirovna. (2021). Ideas about an ideal person, language, prosperity in the evolution of public and political views of the uzbek jadids of the beginning of the xx century. Eurasian Journal of Academic Research, 1(3), 5-8. http://doi.org/10.5281/zenodo.4925897 